\title{
Brain size and cognitive ability: Correlations with age, sex, social class, and race
}

\author{
J. PHILIPPE RUSHTON and C. DAVISON ANKNEY \\ University of Western Ontario, London, Ontario, Canada
}

\begin{abstract}
Using data from magnetic resonance imaging (MRI), autopsy, endocranial measurements, and other techniques, we show that (1) brain size is correlated with cognitive ability about .44 using MRI; (2) brain size varies by age, sex, social class, and race; and (3) cognitive ability varies by age, sex, social class, and race. Brain size and cognitive ability show a curvilinear relation with age, increasing to young adulthood and then decreasing; increasing from women to men; increasing with socioeconomic status; and increasing from Africans to Europeans to Asians. Although only further research can determine if such correlations represent cause and effect, it is clear that the direction of the brain-size/cognitive-ability relationships described by Paul Broca (1824-1880), Francis Galton (1822-1911), and other nineteenth-century visionaries is true, and that the null hypothesis of no relation, strongly advocated over the last half century, is false.
\end{abstract}

With new technologies increasingly available for scanning the brain, and renewed interest in the evolutionary basis of behavior, remarkable discoveries are being made that confirm relationships first established over 100 years ago. Four main procedures have been used to estimate brain size. In the past, these included weighing wet brains at autopsy, measuring the volume of empty skulls using filler, and measuring external head sizes and estimating volume. Recently, more sophisticated techniques have been added to the arsenal, including computer assisted tomography (CAT) and magnetic resonance imaging (MRI) to create, in vivo, three-dimensional images of the brain. Data derived from independent procedures enhance probability of finding truth.

Paul Broca (1824-1880), the renowned French neurologist, made major contributions to refining early techniques for estimating brain size. He concluded that variation in brain size was related to intellectual achievement: mature adults had larger brains than did either children or the very elderly; skilled workers had larger brains than did unskilled workers; eminent individuals had larger brains than did those less eminent; men had larger brains than did women; and Europeans had larger brains than did Africans. Such conclusions were widely accepted in the nineteenth century (e.g., Broca, 1861; Darwin, 1871; Morton, 1849; Topinard, 1878).

Following World War II (1939-1945) and the revulsion toward Hitler's racial policies, however, craniometry became associated with extreme forms of racial preju-

We thank E. Hunt, D. N. Jackson, A. R. Jensen, S. Johnson, P. Kyllonen, H. L. Roediger III, E. Tulving, J. Wickett, L. Willerman, and several anonymous reviewers for valuable comments and suggestions. This review draws on what we have previously published individually and jointly elsewhere. Correspondence should be addressed to J. P. Rushton, Department of Psychology, University of Western Ontario, London, ON, Canada N6A 5C2 (e-mail: rushton@sscl.uwo.ca). dice. After the U.S. civil rights movement became prominent in the 1960 s, research on brain size and intelligence, and group differences therein, virtually ceased and the literature underwent vigorous critiques, notably from Philip V. Tobias (1970), Leon Kamin (1974), and Stephen Jay Gould $(1978,1981)$. In particular, Gould reanalyzed Morton's (1849) work and alleged "unconscious... finagling" and "juggling" (1978, p. 503). In his widely cited Mismeasure of Man, which has become a standard reference guide to this literature, Gould $(1981$, p. 65$)$ suggested how biases could be introduced into such data:

Plausible scenarios are easy to construct. Morton, measuring by seed, picks up a threateningly large black skull, fills it lightly and gives it a few desultory shakes. Next, he takes a distressingly small Caucasian skull, shakes hard and pushes mightily at the foramen magnum with his thumb. It is easily done, without conscious motivation; expectation is a powerful guide to action.

In a book whose title clearly stated their opinion, Not in Our Genes, Lewontin, Rose, and Kamin (1984) went even further, implying that the self-deluded prejudice was intentional (p. 52):

The systematic distortion of the evidence by nineteenthcentury anatomists and anthropologists in attempts to prove that the differences in brain size between male and female brains were biologically meaningful, or that blacks have smaller brains than whites has been devastatingly exposed in a detailed reevaluation by Stephen J. Gould.

However, Gould's $(1978,1981)$ charge that Morton (1849) doctored his results to show Caucasian racial superiority has been called into question. A random sample of the Morton collection was remeasured by Michael (1988), who found that very few errors had been made and that these were not in the direction that Gould had asserted. Instead, errors were found in Gould's own work. Michael (1988, p. 353) concluded that Morton's research 
"was conducted with integrity... [while] Gould is mistaken." As we shall show, "politically correct" and "egalitarian" conclusions in favor of the null hypothesis do not hold. Modern studies confirm many of Broca's (1861) and Morton's (1849) observations.

We emphasize at the outset that enormous variability exists within each of the populations to be discussed. Because group distributions overlap substantially on the variables in question, with average differences amounting to between $4 \%$ and $34 \%$, it is highly problematic to generalize from group averages to individuals. Nonetheless, as we show, significant among-group variation in brain size and cognitive ability does exist. This is not to say, as some readers might implicitly assume, that brain-size/cognitiveability differences are due entirely to genetic factors. Individual brain size (and cognitive ability) can be affected by nutrition and early experience (Eysenck, 1991a, 1991b; Lynn, 1993b). We later describe a twin study of Whites and Blacks, boys and girls, estimating that only about $50 \%$ of cranial size variation is due to genetic factors (Rushton \& Osborne, 1995).

We also emphasize that nearly all relationships reported in this paper are correlational. Although we report on parallel relationships between brain size and cognitive ability across age, sex, socioeconomic, and racial groups, causal relationships cannot be demonstrated without longitudinal analysis of individuals. Moreover, it is important to note that we primarily report on those mental abilities measured by intelligence tests, although occasionally we use grades and educational or occupational level. "Practical" and "social" intelligence (Sternberg, 1988), or "knowledge," separate from fluid or general $(g)$ intelligence, are typically not included in our discussion.

Herein, we use the terms East Asian, European, and African to denote people either from or derived from these geographic areas, that is, to denote people from the three major geographic races of humankind. Sometimes the literature refers to these populations as Orientals, Whites, and Blacks (also as Mongoloids, Caucasoids, and Negroids; Stringer \& Andrews, 1988). Further, we sometimes use modifiers (e.g., European Americans, White Canadians) and sometimes national ethnic group names (e.g., Irish, Guatemalan Indian) to describe some samples more precisely.

\section{BRAIN SIZE AND INTELLIGENCE}

Galton (1888) was one of the first to quantify the brain-size/cognitive-ability relationship in humans. Galton's subjects were 1,095 Cambridge undergraduate men divided into those who had achieved first-class honors degrees and those who had not. Galton computed head volume by multiplying head length by breadth by height and plotting the results against age (19 to 25 years) and class of degree (A, B, C). He reported that (1) cranial capacity continued to grow after age 19 , and (2) men who obtained high honors degrees had a brain size from $2 \%$ to $5 \%$ greater than those who did not. Pearson (1906) reexamined Galton's data using his newly developed cor- relation coefficient and found a small positive relationship between head size and university grade. This has remained the general observation, with correlations typically ranging from .10 to .40 (Jensen \& Sinha, 1993; Van Valen, 1974; Wickett, Vernon, \& Lee, 1994).

The Appendix summarizes results from 46 samples of the relation between head-size/brain-size and cognitive ability. Clinical samples have been excluded except where clearly identified in the section on imaging techniques. The most representative or average correlation has been reported from those studies providing multiple correlations (e.g., by age and sex or by adjusting for body size). Corrections for body size typically were not included because many studies did not report this statistic (also see below), although age effects were often controlled. Note that we are simply asking whether, within a sample, head size and IQ are correlated. We are not asking what causes head size variations. Double entries were eliminated, particularly those emanating from the U.S. National Collaborative Perinatal Project (Broman, Nichols, Shaughnessy, \& Kennedy, 1987). Not included in the Appendix are typological studies showing that gifted children have larger heads than average (Fisch, Bilek, Horrobin, \& Chang, 1976; Terman, 1926/1959), and mentally defective children have smaller heads than average (Broman et al., 1987; Hack et al., 1991).

The 46 samples are categorized into four sections. Section A shows results of 17 studies that took external head measurements from a total of 45,056 children and adolescents and correlated these with estimates of mental ability from ratings, grades, and standardized tests. Correlations ranged from .08 to .35 , with an unweighted mean of .21 (when weighted by sample size, .20). Section B shows results from 15 studies of adult head size/cognitive ability (total $N=6,437$ people). Correlations ranged from .02 to .39 , with an unweighted mean of .15 (when weighted by sample size, also .15). Note that the head-size/IQ relation has been found in both sexes and in East Asians, East Indians, Europeans, Africans, and Amerindians. Section C shows the results of 7 clinical samples using a total of 312 adults with brain size estimated by CAT and MRI and cognitive ability estimated by educational achievement or by standardized tests. Correlations ranged from .07 to .38 , with an unweighted mean of 24 (when weighted by sample size, .22). Section D shows the results of 8 nonclinical samples with a total of 381 adults with brain size estimated by CAT and MRI and cognitive ability estimated by educational and occupational achievement or by standardized tests. Correlations ranged from .33 to .69 , with an unweighted mean of .44 (when weighted by sample size, .42).

We obtained the exact $p$ values of all correlations in the Appendix and, using Fisher's (1970, pp. 99-101) method for combining independent probabilities, calculated the overall $p$ value, which was less than $10^{-10}$. However, as Stott (1983, p. 286) noted in his critical review of the literature on brain size and intelligence, it is possible that "when correlations are small and on the borderline of significance, as was the case involving intelligence and head size, there is no means of ascertaining 
how many studies producing results below the level of significance have been allowed to lie unreported."

Most, although not quite all, of the correlations in the Appendix reached significance, and none were in the opposite direction. Only one negative report, a null finding, has come to our attention. Teasdale and Pakkenberg (1988) estimated brain volume from autopsy data in 26 institutionalized schizophrenic patients in Sweden (14 men and 12 women with a mean age of 73 years at death) and rated their intelligence on a 3 -point scale based on hospital records. After adjusting for effects of age and sex, Teasdale and Pakkenberg reported a correlation between brain size and cognitive ability of -.05 (n.s.). The sample size was small and the measure of intelligence questionable, so without additional information to the contrary, the correlation between head size/brain size and cognitive ability must be considered an established fact.

Two reviewers suggested that our presentation in the Appendix rests on the inappropriate assumption that different studies are equally valid in terms of sample size and nature, measurement of head or brain, and test of mental ability, and suggested that we should report only those studies providing the "best evidence." Because schizophrenics tend to be tall with small heads (Kretschmer, 1936), and because shrinkage of the brain occurs in some patient populations, it is possible to further criticize our inclusion of studies of cognitive ability among schizophrenics and of those with medically unconfirmable neurologic symptoms (e.g., Yeo, Turkheimer, Raz, \& Bigler, 1987; DeMyer et al., 1988). Our view, however, is that it is preferable to show readers all known data sets concerning brain size and cognitive ability. We are impressed by the replication of the correlations between head size/brain size and cognitive ability over such a long period of time and over such a wide range of subjects and testing situations. If we took the reviewers' suggestions and examined only those studies using MRI and other imaging techniques, the correlation would be considerably higher than from most of the other estimates in the Appendix. This makes sense, if one assumes that there is less error variance in imaging techniques, so that the reliability of the measure is higher and therefore the correlation between brain size and IQ is greater. Moreover, the eight imaging samples in Section D, totaling 381 normals, yielded a mean $r$ of .44 (when weighted by sample size, .42 ), whereas the seven samples in Section $C$, totaling 312 patients, yielded a correlation of $r=.24(.22$ when weighted for sample size). Thus we consider our procedures conservative.

A functional relation between head size and cognitive ability has been implied in two studies showing that the relation exists within families as well as among them. A tendency for a sibling with a larger head to have a higher IQ than a sibling with a smaller head is of special interest, because it controls for many of the sources of variance that distinguish families such as cultural background and socioeconomic status. Jensen (1994) examined 82 pairs of monozygotic and 61 pairs of dizygotic adolescent twins and extracted the general factor, or psychometric $g$, from their IQ tests and found that it correlated with head size across individuals $(r=.30)$, within twin pairs $(r=.25)$, and between twin pairs $(r=.32)$. Jensen and Johnson (1994) examined the head-size/IQ relation in some 14,000 pairs of siblings from the Collaborative Perinatal Project (Broman et al., 1987) almost evenly divided by race (White/Black) and sex, for whom data, including test data, were obtained at ages 4 and 7 years. Within each race by sex group, IQ showed low but significant correlations with head circumference after age and body size were partialed out. For White boys and White girls, and Black boys and Black girls, respectively, at age 4, $r \mathrm{~s}=.14, .16, .07$, and .07 , and at age $7, r \mathrm{~s}=.21, .21$, .14 , and .15; all correlations significant at $p<.001$, twotailed. At age 7 (although not at age 4 ) the significant correlation existed within families $(r=.11)$ as well as between families $(r=.20)$.

It is reasonable to expect that brain size and cognitive ability are related because Haug $(1987$, p. 135) showed a correlation of $r=.479(n=81, p<.001)$ between number of cortical neurons (based on a partial count of representative areas of the brain) and brain size, including both men and women in the sample. The regression equating the two was given as (\# of cortical neurons [in billions] = $5.583+0.006\left[\mathrm{~cm}^{3}\right.$ brain volume $]$ ). This means that a person with a brain size of $1,400 \mathrm{~cm}^{3}$ has, on average, 600 million fewer cortical neurons than an individual with a brain size of $1,500 \mathrm{~cm}^{3}$. The difference between the low end of normal $\left(1,000 \mathrm{~cm}^{3}\right)$ and the high end $\left(1,700 \mathrm{~cm}^{3}\right)$ works out to be 4.200 billion neurons (a difference of $27 \%$ more neurons from a $41 \%$ increase in brain size). The human brain may contain up to 100 billion $\left(10^{11}\right)$ nerve cells classifiable into 10,000 types resulting in 100,000 billion synapses (Kandel, 1991). Even storing information at the low average rate of one bit per synapse, which would require two levels of synaptic activity (high and low), the structure as a whole would generate $10^{14}$ bits. Contemporary supercomputers, by comparison, command a memory of about $10^{9}$ bits of information.

It is also predictable, however, that correlations between IQ and overall brain size will be modest. First, much of the brain is not involved in producing what we call intelligence; thus, variation in size/mass of that tissue will lower the magnitude of the correlation. Second, IQ, of course, is not a perfect measure of intelligence and, thus, variation in IQ scores is an imperfect measure of variation in intelligence.

Although brain size accounts for only a small percentage of variation in cognitive ability, it is important to note, following Rosenthal (1984) and Hunter and Schmidt (1990), that small correlations can have large effects. For example, although the MRI-established brain-size/ IQ correlation is only about .40, when squared, it shows that $16 \%$ of the variance is explained, and it also shows that, from regression predictions, for every 1 standard deviation increase in brain size, IQ will increase, on average, by 0.40 standard deviations.

Brain size is correlated positively to body size. For example, results from autopsy studies such as the one by 
Dekaban and Sadowsky (1978) of 2,773 men and 1,963 women, as well as the one by Ho, Roessmann, Straumfjord, and Monroe (1980a, 1980b) of 644 men and 617 women, suggest a correlation of about .20 between brain mass (grams) and stature and body mass. Similarly, MRI studies yield an average correlation of about .20 (Pearlson et al., 1989; Wickett et al., 1994). The brain-size/ body-size relationship is higher $(.30-.40)$ with measures of the skull $\left(\mathrm{cm}^{3}\right)$, either estimated from endocranial volume or from external head measures. For example, in a stratified random sample of 6,325 U.S. servicemen, cranial capacity correlated, on average, .38 with height and .41 with mass in 2,803 women and 3,522 men (Rushton, 1992a).

There is, however, disagreement about whether or not brain size should be corrected for body size before brainsize/IQ correlations are examined (Jensen \& Sinha, 1993; Rushton \& Ankney, 1995). As noted by Rushton and Ankney, controlling for body size changes the question from "Is IQ correlated with absolute brain size?" to "Is IQ correlated with relative brain size?" Although these are quite different questions, evidence shows that the answer to both is "yes" (see Egan, Wickett, \& Vernon, 1995). Controlling for body size can be regarded to some degree as an overcorrection because head size itself is part of stature and body weight.

\section{AGE DIFFERENCES}

\section{Brain Size}

Autopsy studies show that brain mass increases during childhood and adolescence and then, beginning as early as 20 years, slowly decreases through middle adulthood and finally more quickly decreases in old age (Dekaban \& Sadowsky, 1978; Ho et al., 1980a, 1980b; Pakkenberg \& Voigt, 1964; Voigt \& Pakkenberg, 1983). Ho et al.'s (1980a, 1980b) data, collated for 2,037 subjects from autopsy records, for various subgroups, 1,261 of them between the ages of 25 and 80 , are shown in Figure 1. All brains were weighed on the same balance at the Institute of Pathology at Case Western Reserve University after those brains with lesions or other abnormalities were excluded. The average mass of the brain increases from $397 \mathrm{~g}$ at birth to $1,180 \mathrm{~g}$ at 6 years. Growth then slows and brain mass peaks at about $1,450 \mathrm{~g}$ before the age of 25 years. The mass declines slowly from age 26 to 80 years, an average of $2 \mathrm{~g}$ per year $(N \mathrm{~s}$ at $30,40,50,60,70$, 80 , and $90=48,98,225,365,365,211$, and 79 , respectively). The decrease after age 80 years is much steeper, the loss being $5 \mathrm{~g}$ per year. As shown in Figure 1, although rate of mass decrease varies slightly, it is essentially similar for various subgroups.

From birth through childhood, brain mass at autopsy is correlated with head perimeter at between 0.80 to 0.98 (Brandt, 1978; Bray, Shields, Wolcott, \& Madsen, 1969; Cooke, Lucas, Yudkin, \& Pryse-Davies, 1977). The correlation between brain mass and head perimeter in adults, however, is unknown and may be as low as .50 (Van Valen, 1974). Head perimeter and cranial capacity, like brain

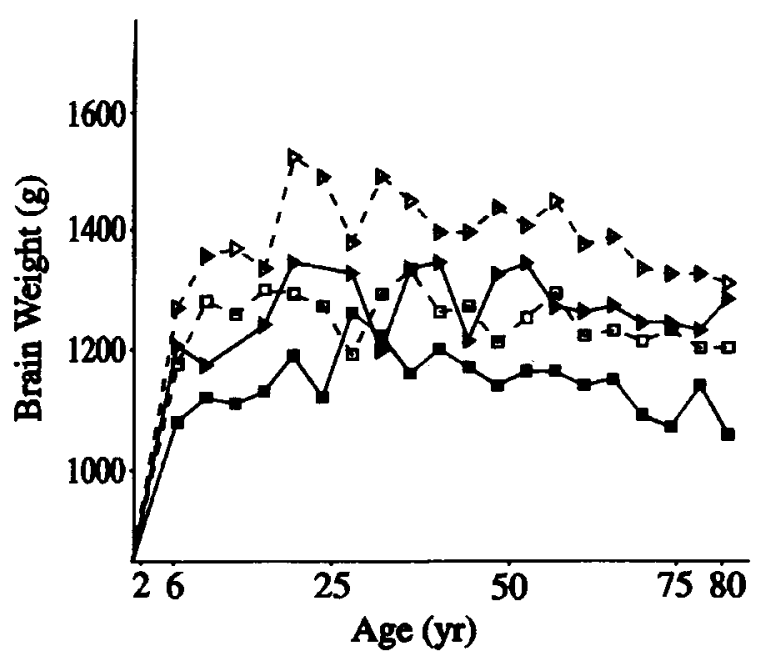

Figure 1. Mean brain weight for 4-year age periods in various subgroups. Brain weight is plotted at midpoint of each age period (e.g., point at age 6 years represents average for cases between 4 and 8 years); White men, open triangles; Black men, solid triangles; White women, open squares; Black women, solid squares. Differences in brain weights among various groups become apparent at age 6 years. From "Analysis of Brain Weight: I. Adult Brain Weight in Relation to Sex, Race, and Age," by K. C. Ho, U. Roessmann, J. V. Straumfjord, and G. Monroe, 1980, Archives of Pathology and Laboratory Medicine, 104, p. 636. Copyright 1980 by the American Medical Association. Reprinted with permission.

mass at autopsy, also increase with age. The Collaborative Perinatal Project (Table 1), mentioned earlier, followed nearly 40,000 children from conception to age 7 years. For these children, head perimeter was measured at birth, 4 months, 1 year, 4 years, and 7 years (and the Bayley Mental Scale was given at 8 months, the StanfordBinet at 4 years, and the Wechsler at 7 years). Head perimeters increased with age and showed individual consistency. For White children, head perimeter at birth correlated 0.47 with that at 7 years, and for Black children the correlation was .39. (And, for both races combined, Bayley IQ scores at 8 months and the Binet IQ scores at age 4 correlated .25 and .62 , respectively, with Wechsler IQ scores at age 7. For both White and Black children, head perimeter at all ages predicted test scores at age 7 .

Cranial capacity estimated from external head measures also increases from age 7 to as late as age 25 as originally shown by Galton (1888). The cranial capacities of 4,012 White Australian boys were tabulated by Jensen and Sinha (1993; from a study by Miller, 1926) and shown to increase from $1,255 \mathrm{~cm}^{3}$ at age 7 to $1,440 \mathrm{~cm}^{3}$ at age 17. Head size data on 236 pairs of adolescent twins (472 individuals, Blacks and Whites, boys and girls) were analyzed by Rushton and Osborne (1995). Collapsing across sex and race, cranial capacity increased from $1,233 \mathrm{~cm}^{3}$ at age 13 to $1,279 \mathrm{~cm}^{3}$ at age 17 . We have calculated cranial capacities from head-size data for a core longitudinal sample of 748 middle-class White and Black children provided by Krogman (1970), and ana- 
Table 1

Head Circumference by Age and Race and Correlations With IQ at 7 Years

\begin{tabular}{|c|c|c|c|c|c|c|c|c|}
\hline \multirow[b]{2}{*}{ Age } & \multicolumn{4}{|c|}{ Whites } & \multicolumn{4}{|c|}{ Blacks } \\
\hline & $\begin{array}{l}\text { Sample } \\
\text { Size }\end{array}$ & $\begin{array}{l}\text { Circumference } \\
(\mathrm{cm})\end{array}$ & $S D$ & $r \dagger$ & $\begin{array}{l}\text { Sample } \\
\text { Size }\end{array}$ & $\begin{array}{c}\text { Circumference } \\
(\mathrm{cm})\end{array}$ & $S D$ & $r \dagger$ \\
\hline Birth & 16,877 & 34.0 & 1.5 & .13 & 18,883 & 33.4 & 1.7 & .12 \\
\hline 4 months* & 15,905 & 40.9 & 1.4 & .19 & 17,793 & 40.4 & 1.6 & .16 \\
\hline 1 year & 14,724 & 45.8 & 1.5 & .20 & 16,786 & 45.6 & 1.5 & .15 \\
\hline 4 years & 12,454 & 50.1 & 1.5 & .21 & 14,630 & 49.9 & 1.6 & .16 \\
\hline 7 years & 16,949 & 51.5 & 1.5 & .24 & 18,644 & 51.2 & 1.6 & .18 \\
\hline
\end{tabular}

Note-Data have been calculated from Broman, Nichols, Shaughnessy, \& Kennedy (1987, p. 104, Table 610; p. 220, Table 9-28; p. 226, Table 9-34; p. 233, Table 9-41; p. 247, Table 9-54). From Race, Evolution, and Behavior (p. 40), by J. P. Rushton, 1995, New Brunswick, NJ: Transaction. Copyright 1995 by Transaction Publishers. Reprinted with permission. ${ }^{*}$ Contains up to $2 \%$ of children with damage to central nervous system. $\quad t p<.00001$

lyzed for sex and race differences by Lynn (1993a), and found that cranial capacity increased from $1,160 \mathrm{~cm}^{3}$ at age 7 to $1,340 \mathrm{~cm}^{3}$ at age 15 .

MRI investigations also show a curvilinear pattern of growth and change, with an overall decrease in brain volume following the late teens as gray matter is replaced with cerebrospinal fluid (range of $r \mathrm{~s}=-.32$ to -.71; Gur et al., 1991; Jernigan et al., 1991; Pfefferbaum et al., 1994; Resnick, 1995). Pfefferbaum et al. (1994) demarcated cell growth, myelination, pruning, and atrophy. With a sample of 88 male and female subjects aged 3 months to 30 years, cortical gray matter volume (mainly cell bodies) peaked at around age 4 years and then declined steadily throughout the life span; cortical white matter volume (myelin sheath) increased steadily until about age 20 years and appeared stable thereafter; and the volume of cortical cerebrospinal fluid remained stable from 3 months to 20 years. In a sample of 73 male subjects aged 21 to 71 years, cerebrospinal fluid increased exponentially over the five decades of adulthood studied. Ventricular enlargement from age 20 to 30 years suggested a possible marker for the onset of atrophy, whether due to cell loss or cell shrinkage. Other data, reviewed by Miller (1994), suggest that myelin effectiveness decreases with aging. Incidentally, these modern data on age-related brain atrophy confirm Broca's (1861) original data from the nineteenth century (as reanalyzed by Schreider, 1966).

\section{Cognitive Ability}

Typically, mental ability measures increase during childhood and adolescence, decrease slowly between age 25 and 45 , and decrease more quickly after age 45 . It once was claimed that this age-related decline in IQ was spurious because early longitudinal studies contradicted findings from cross-sectional studies; thus, the crosssectional observations were derogated as a generation or "cohort" effect, perhaps due to "more favorable" environments for younger cohorts (Schaie \& Strother, 1968). However, subsequent longitudinal studies, reviewed by Brody (1992), have corroborated results from cross-sectional studies. Brody (1992, p. 238) concluded: "Declines in fluid ability over the life span up to age $80 \mathrm{might}$ well average 2 standard deviations."

\section{SEX DIFFERENCES}

\section{Brain Size}

An absolute difference in brain size between men and women has not been disputed since at least the time of Broca (1861). It is often claimed, however, that the sex difference disappears when corrections are made for body size or age of people sampled (Gould, 1981; Lewontin et al., 1984). Nevertheless, a recent study by Ankney (1992) demonstrated that the sex difference in brain size remains after correction for body size in a sample of similarly aged men and women (following tentative results by Dekaban \& Sadowsky, 1978; Gur et al., 1991; Hofman \& Swaab, 1991; Holloway, 1980; Swaab \& Hofman, 1984; Willerman, Schultz, Rutledge, \& Bigler, 1991).

Ankney (1992) argued that the large sex difference in brain size went unnoticed for so long because earlier studies used improper statistical techniques to correct for sex differences in body size, and, thus, incorrectly made a large difference "disappear." The serious methodological error was the use of brain-mass/body-size ratios instead of analysis of covariance (see Packard \& Boardman, 1988). Ankney (1992) illustrated why this is erroneous by showing that, in both men and women, the ratio of brain mass to body size declines as body size increases. Thus, as can be seen in Figure 2, larger women have a lower ratio than do smaller women, as do larger men compared to smaller men. Therefore, because the average-sized man is larger than the average-sized woman, their brain-mass to body-size ratios are similar (Figure 2). Consequently, the only meaningful comparison is that of brain-mass to body-size ratios of men and women of equal size. Such comparisons show that at any given size, the ratio of brain mass to body size is much higher in men than in women (Figure 2).

Ankney reexamined autopsy data on 1,261 American adults (Ho et al., 1980a, 1980b) and found that at any given body surface area or height, brains of White men are heavier than those of White women, as are brains of Black men compared to those of Black women. For example, among 168-cm $\left(5^{\prime} 7^{\prime \prime}\right)$ tall Whites (the approximately overall mean height for men and women combined), brain mass of men averages about $100 \mathrm{~g}$ heavier than that of women (Figure 3), whereas the average dif- 


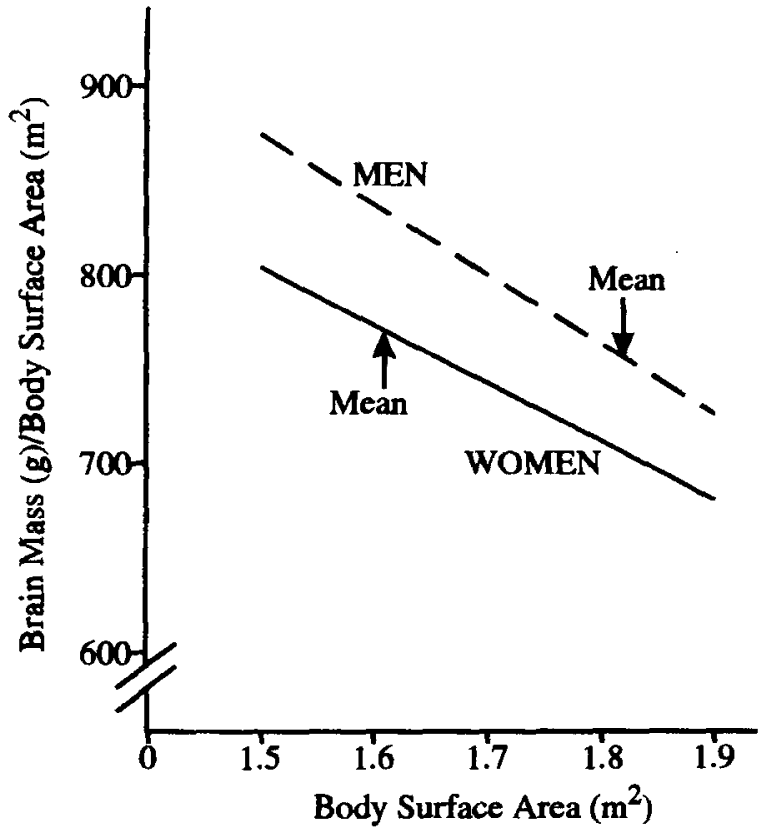

Figure 2. The relation between the ratio of brain-mass/bodysurface area and body-surface area in White men and women. Ankney (1992) calculated the ratios by estimating brain mass at a given body surface area using the equations in Ho et al. (1980b, Table 3): men, brain mass $=1,077 \mathrm{~g}( \pm 56)+173( \pm 31) \times$ body surface area $(r=.27, p<.01)$; women, brain mass $=949 \mathrm{~g}( \pm 52)$ $+188( \pm 32) \times$ body surface area $(r=.24, p<.01)$. From "Sex Differences in Relative Brain Size: The Mismeasure of Woman, Too?" by C. D. Ankney, 1992, Intelligence, 16, p. 331. Copyright 1992 by Ablex Publishing Corporation. Reprinted with permission.

ference in brain mass, uncorrected for body size, was $140 \mathrm{~g}$. Thus, only about $30 \%$ of the sex difference in brain size is due to differences in body size.

Ankney's results were confirmed in a study of cranial capacity in a stratified random sample of 6,325 U.S. Army personnel (Rushton, 1992a). After adjustment, via analysis of covariance, for effects of age, stature, weight, military rank, and race, men averaged $1,442 \mathrm{~cm}^{3}$ and women $1,332 \mathrm{~cm}^{3}$. This difference was found in all of the 20 or more separate analyses shown in Figure 4, done to rule out any body-size effect (see also Rushton, 1992a; pp. 406-408). Moreover, the difference was replicated across samples of Asians, Whites, and Blacks, as well as across officers and enlisted personnel. Parenthetically, in the Army data, Asian women constituted the smallest sample $(N=132)$, and it is probable that this caused the "instability" in estimates of their cranial size when some corrections were made for body size (Figure 4). The sex difference of $110 \mathrm{~cm}^{3}$ found by Rushton, from analysis of external head measurements, is remarkably similar to that $(100 \mathrm{~g})$ obtained by Ankney, from analysis of brain mass $\left(1 \mathrm{~cm}^{3}=1.036 \mathrm{~g}\right.$; Hofman, 1991).

Other studies have confirmed the sex difference. Rushton (1994) calculated cranial sizes from data on tens of thousands of men and women aged 25 to 45 collated by the International Labour Office in Geneva and found, after adjustments for body size, differences favoring men of $127 \mathrm{~cm}^{3}$ in East Asian countries, $163 \mathrm{~cm}^{3}$ in European countries, and $193 \mathrm{~cm}^{3}$ in African countries. (Before adjustments for body size, the figures are, respectively, 190 , 223 , and $256 \mathrm{~cm}^{3}$ ). Andreasen (1993) corroborated the sex difference in adult brain size using MRI (see also Gur et al. 1991; Harvey, Persaud, Ron, Baker, \& Murray, 1994; Resnick, 1995; Willerman et al., 1991).

From birth through early months, we found the sex difference held in several autopsy studies when, following Ankney's (1992) procedure (Figure 3), we compared brain masses of boys and girls after matching them for stature (Dekaban \& Sadowsky, 1978; Pakkenberg \& Voigt, 1964; Voigt \& Pakkenberg, 1983). In children from 4 to 7 years of age, sex differences are found with brain size inferred from external head measurements. After adjustments for body size and race, sex differences in head perimeter are about $0.40 S D$ (Jensen \& Johnson, 1994). From 7 to 17 years, sex differences in cranial capacity are in the range of 60 to $100 \mathrm{~cm}^{3}$ (Lynn, 1993a; Rushton \& Osborne, 1995).

\section{Cognitive Ability}

These results present a paradox. Women have proportionately smaller brains than do men, but apparently have the same intelligence test scores. According to Kimura (1992), however, women excel in verbal ability, perceptual speed, and motor coordination within personal space,

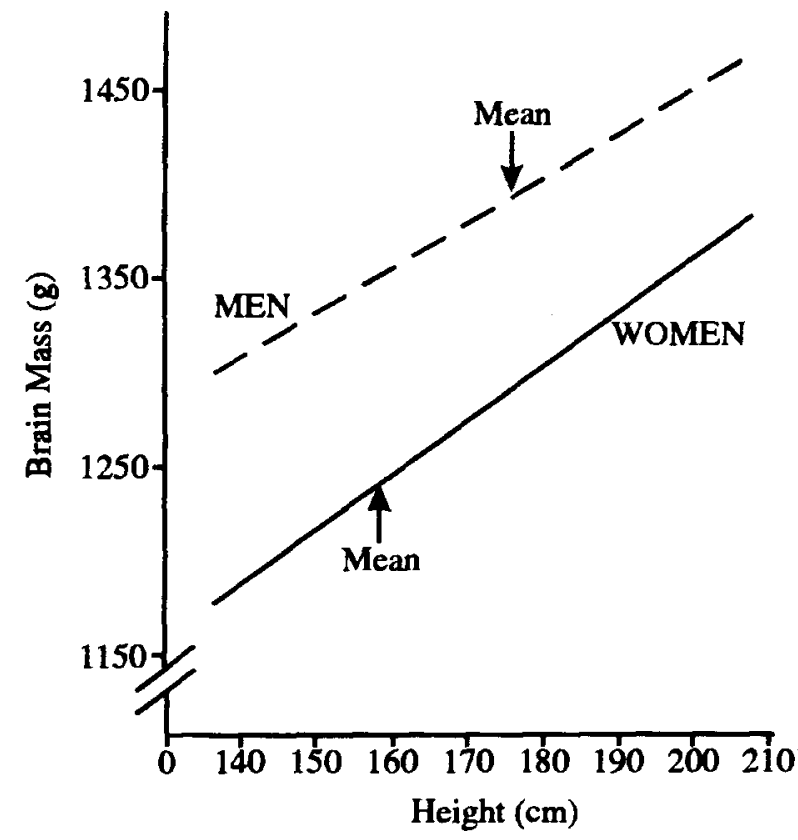

Figure 3. The relation between brain mass and body height in White men and women. Lines drawn from equations in Ho et al. $(1980 \mathrm{~b}$, Table 1): men, brain mass $=920 \mathrm{~g}( \pm 113)+2.70( \pm .65)$ $x$ body height $(r=.20, p<.01)$; women, brain mass $=748 \mathrm{~g}$ $( \pm 104)+3.10( \pm .64) \times$ body height $(r=.24, p<.01)$. From "Sex Differences in Relative Brain Size: The Mismeasure of Woman, Too?" by C. D. Ankney, 1992, Intelligence, 16, p. 333. Copyright 1992 by Ablex Publishing Corporation. Reprinted with permission. 


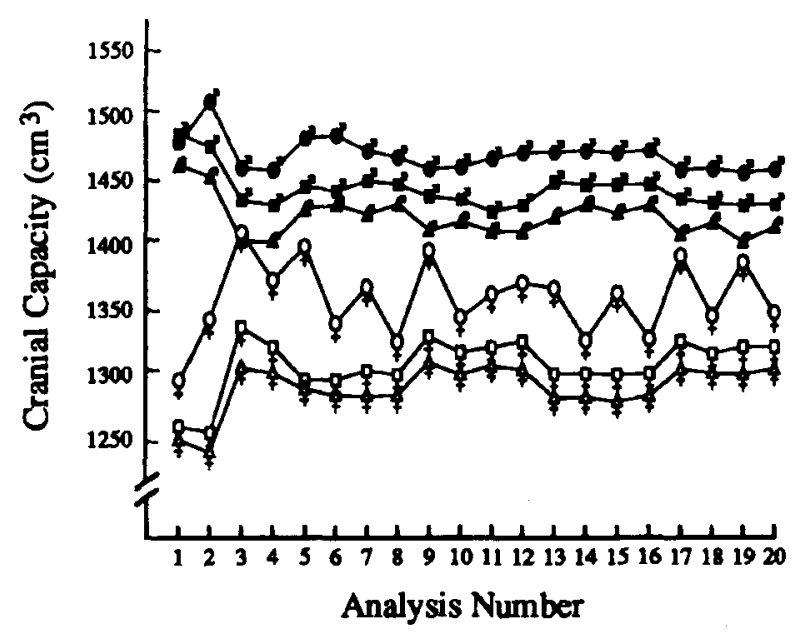

Figure 4. Cranial capacity for a stratified random sample of 6,325 U.S. Army personnel. The data, grouped into six sex-byrace categories, are collapsed across military rank. (Asian men, closed circles; White men, closed squares; Black men, closed triangles; Asian women, open circles; White women, open squares; Black women, open triangles). They show that, across the 19 different analyses controlling for body size, men averaged larger cranial capacities than did women, and Asians averaged larger than did Whites or Blacks. Analysis 1 presents the data unadjusted for body size showing no difference for Asian and European men. Adapted from "Cranial Capacity Related to Sex, Rank, and Race in a Stratified Random Sample of 6,325 U.S. Military Personnel," by J. P. Rushton, 1992, Intelligence, 16, p. 408. Copyright 1992 by Ablex Publishing Corporation. Adapted with permission.

whereas men do better on various spatial tests and on tests of mathematical reasoning. Although controversy exists about the magnitude of the sex difference in spatial ability under various testing conditions, reviews by Pool (1994) and Voyer, Voyer, and Bryden (1995) have shown that on the "purest" spatial measures, such as rotating an imaginary object, or shooting at a moving rather than a stationary target, the sex difference approaches 1 standard deviation. Thus, Ankney $(1992,1995)$ hypothesized, the sex difference in brain size relates to those intellectual abilities at which men excel, that is, spatial and mathematical abilities require more "brain power." Analogously, whereas increasing word-processing power in a computer requires some extra capacity, increasing 3-dimensional processing, as in graphics, requires a major increase in capacity.

The nineteenth century proposition that men average slightly higher in general intelligence than do women (e.g., Broca, 1861 , p. 153) has also been reactivated. Lynn's (1994) resolution of the paradox of the sex difference in brain size was to contradict (with evidence) the consensus view that there is no difference in general intelligence. He reviewed data from Britain, Greece, China, Israel, the Netherlands, Norway, Sweden, and Indonesia, as well as the United States, to show that men averaged about 4 IQ points higher than did women on a number of published intelligence tests. Independently, Jackson (1993) reported a 12 percentile point advantage to men in a general factor of ability extracted from data from 180,000
German medical school applicants and, from the same data set, Stumpf and Jackson (1994) reported a half-standard deviation advantage to men in reasoning ability. Subsequently, Jackson (1995) showed an 8 percentile advantage for men on a general cognitive ability factor extracted from the U.S. Scholastic Aptitude Test $(N=$ 112,516 individuals).

\section{SOCIOECONOMIC STATUS (SES) DIFFERENCES}

\section{Brain Size}

Nineteenth- and early twentieth-century data from Broca (1861) and others (Hooton, 1939; Sorokin, 1927; Topinard, 1878) suggested that people in higher status occupations averaged a larger brain or head size than did those in lower ones. For example, Galton collected head measurements, and information on educational and occupational background, from thousands of individuals at his laboratory in the South Kensington Natural Science Museum in London. However, he had no statistical method for testing the significance of the differences in head size between various occupational/educational groups. Nearly a century later, Galton's data were analyzed by Johnson, McClearn, Yuen, Nagoshi, Ahern, and Cole (1985), who found that professional and semiprofessional groups averaged significantly larger head sizes (both length and width) than did unskilled groups. The results were striking for men but less clear-cut for women. We have calculated cranial capacities from Johnson et al.'s (1985) summary of Galton's head-size data and found that cranial capacity increased from unskilled to professional classes from 1,324 to $1,468 \mathrm{~cm}^{3}$ in men but only from 1,256 to $1,264 \mathrm{~cm}^{3}$ in women. These figures are uncorrected for body size.

A relationship between head size and occupational status has also been found after correction for body size. Reviewing much of the literature, Jensen and Sinha (1993) drew an important distinction between a person's SES of origin, which is the SES attained by the person's parents, and attained SES, which is the level of SES attained by the person in adulthood. Correlations of IQ, head size, and other variables are always smaller when derived from "SES of origin" than when derived from "attained SES."

The largest set of data on head circumference, from a report by Broman, Nichols, and Kennedy (1975) on approximately 10,000 White and 12,000 Black 4-year-old children, was analyzed by Jensen and Sinha (1993) and showed a small but significant correlation with social class of origin within both White and Black populations, after height was controlled $(r=.10)$. Jensen and Sinha (1993) also reanalyzed autopsy data reported by Passingham (1979) on 734 men and 305 women and found an overall correlation between brain mass and achieved occupational level of about .25, independent of body size. Although these correlations are small, they are lower bound estimates uncorrected for unreliability of measurement and sex differences in brain size. 
Pearlson et al. (1989) and Andreasen et al. (1990) used brain imaging techniques and found significant main effects of brain size on occupational status and/or educational level; higher status subjects had, on average, a larger brain than did lower status subjects. Rushton (1992a) used externally measured cranial size of 6,325 U.S. servicemen and found that, both before and after adjusting for effects of stature, weight, race, and sex, officers averaged significantly larger cranial capacities than did enlisted personnel $\left(1,384 \mathrm{vs} .1,374 \mathrm{~cm}^{3}\right.$ before adjustments; 1,393 vs. $1,375 \mathrm{~cm}^{3}$ after adjustments). Further, in each of six separate sex (men, women) by race (Asian, White, Black) comparisons, officers had a significantly greater cranial capacity than did enlisted personnel.

\section{Cognitive Ability}

The socioeconomic hierarchies of modern societies in Europe, North America, and Japan are significantly correlated with scores on standard IQ tests (Gottfredson, 1986; Herrnstein \& Murray, 1994; Jensen, 1993a). The basic finding is that there is a difference of nearly 3 standard deviations ( 45 IQ points) between average members of professional and unskilled classes. These are groupmean differences with considerable overlap of distributions. Nonetheless, the overall correlation between an individual's IQ and his or her SES of origin is between .30 and .40 , and the correlation between IQ and attained SES, or occupational level, is about 0.50 (Herrnstein \& Murray, 1994; Jensen, 1980). In studies of intergenerational social mobility, Mascie-Taylor and Gibson (1978) and Waller (1971) obtained IQ scores of fathers and their adult sons. They found that, on average, children with lower test scores than their fathers had gone down in social class as adults, but those with higher test scores had gone up.

\section{RACE DIFFERENCES}

\section{Brain Size}

In the following review, we conclude that a gradient exists in brain size from East Asians to Europeans to Africans. As such, we disagree with the prevailing view that the racial differences in brain size established in the nineteenth century disappear when corrections are made for body size and other variables such as "bias." Because of inelegancies in many of the studies, however, only tentative conclusions are warranted, pending more definitive research. Among the problems we encountered in conducting our review were the following: (1) What groups should be included in a racial category? (2) How should we interpret group differences uncorrected for body size? and (3) How should we interpret differences in magnitude of only $1 \%$ to $3 \%$ between races? We decided to (1) focus primarily on East Asians, Europeans, and Africans, so we excluded Amerindians, Australian Aboriginees, and East Indians; (2) correct for body size whenever possible, as we did earlier in the section on sex differences; and (3) assume that because a $1 \%$ difference of $14 \mathrm{~cm}^{3}$ in brain size translates into millions of neurons and hundreds of millions of synapses (Haug, 1987), they are not as "miniscule" as they might appear.

In an analysis highly critical of the early literature on wet brain mass measured at autopsy, Tobias (1970) held that all interracial comparisons were "invalid," "misleading," and "meaningless" because 14 crucial variables had been left uncontrolled. In one study or another, these included "sex, body size, age of death, nutritional state in early life, source of the sample, occupational group, cause of death, lapse of time after death, temperature after death, anatomical level of severance, presence or absence of cerebrospinal fluid, of meninges, and of blood vessels" (p. 3). Tobias pointed out that each of these variables alone could increase or decrease brain mass by $10 \%$ to $20 \%$, an amount equivalent to or greater than any purported race differences. He also opposed conclusions of race differences in structural variables such as cortical thickness, size of frontal lobe, or complexity of the brain's convolutions.

Rushton (1988a), however, countered that aggregating across studies typically cancels measurement error, at least nonsystematic measurement error. Calculating the midpoints of the range of scores provided by Tobias (1970, p. 6, Table 2), he found that a "Mongoloid Series" (Tobias's term) averaged 1,368 $\mathrm{g}$, Caucasoids $1,378 \mathrm{~g}$, and Negroids, 1,316 g. Rushton (1988b) also averaged a related measure that took body size into account, that is, the "millions of excess nerve cells" estimated by Tobias for eight subgroups and nationalities (1970, p. 9, Table 3 ). These were the number of neurons available for general adaptive purposes over and above that necessary for maintaining bodily functioning and were derivable from equations based on brain-/body-weight relationships (Jerison, 1963, 1973). Tobias was skeptical of the value of his "exercise" and provided few details. Nonetheless, Rushton (1988b) found, in millions of excess neurons, Mongoloids $=8,990$, Caucasoids $=8,650$, and Negroids $=8,550$. As we shall show, modern studies confirm racial differences in autopsied brain size.

Many more studies have estimated brain size from cranial capacity for, as Baker (1974, p. 429) remarked, "Skulls are many, freshly removed brains are few." The cranial capacity literature, however, has also undergone serious critiques, as in Gould's $(1978,1981)$ reanalysis of Morton's (1849) data described in our Introduction. Rushton (1988a) showed that Morton's data, even as reassessed by Gould (1978, p. 508, Table 6), indicated that in cubic inches, Mongoloids $=85.5$, Caucasoids $=84.5$, and Negroids $=83.0$, which convert to $1,401,1,385$, and $1,360 \mathrm{~cm}^{3}$, respectively. Rushton $(1995$, p. 115 , Table 6.1$)$ also showed that the same racial differences held after a subsequent tabulation by Gould (1981), following an admission by Gould (1981, p. 66) of his own "embarrassing" error in calculating his 1978 figures. In both his 1978 and 1981 writings, Gould dismissed the differences as "trivial." But, as noted, differences of 1 cubic inch $\left(16 \mathrm{~cm}^{3}\right)$ in brain size are not trivial in that they contain literally millions of neurons and hundreds of millions of synapses. 
Modern studies have confirmed earlier findings. Analyzing data on brain mass at autopsy for 1,261 American subjects aged 25 to 80 , after excluding obviously damaged brains, Ho et al. (1980a) reported that brain mass averaged $1,392 \mathrm{~g}$ in 416 White men $(S D=130)$ and 1,286 g in 228 Black men $(S D=138)$, a difference of $106 \mathrm{~g}$. Similarly, brain mass averaged $1,252 \mathrm{~g}$ in 395 White women $(S D=125)$ and $1,158 \mathrm{~g}$ in 222 Black women $(S D=119)$, a difference of $94 \mathrm{~g}$. Although Ho et al. (1980a) did not provide values corrected for age or body size, the race differences in absolute brain mass cannot be explained by those variables: Black men and women in the sample were, on average, virtually identical in age and size to their White counterparts.

Analyzing the world database of about 20,000 skulls, uncorrected for body size, Beals, Smith, and Dodd (1984, p. 307, Table 5) found that the size of sex-combined brain cases differed by continental area. Excluding Caucasoid areas of Asia (e.g., India) and Africa (e.g., Egypt), 19 Asian populations averaged $1,415 \mathrm{~cm}^{3}(S D=51), 10$ European groups averaged $1,362 \mathrm{~cm}^{3}(S D=35)$, and 9 African groups averaged $1,268 \mathrm{~cm}^{3}(S D=85)$. Using MRI to measure brain volume in a combined sample of 108 normal and clinical subjects in Britain aged 18 to 48 years, Harvey et al. (1994) found that 41 non-Caucasians (Africans and West Indians) had a smaller brain volume $(p=.007)$ than did 67 Caucasians, although Harvey et al. (1994) provided little information on ethnicity and no details on how, or if, the samples were matched for age, sex, or body size.

Several studies of cranial capacity calculated from external head measurements were conducted by Rushton, who found, after corrections were made for body size, that East Asians consistently averaged larger crania than did Europeans or Africans. For example, Rushton (1992a) examined a stratified random sample of 6,325 U.S. Army personnel and calculated that for Asians, Whites, and Blacks, cranial capacities corrected for body size averaged $1,416,1,380$, and $1,359 \mathrm{~cm}^{3}$, respectively (Figure 4). In an examination of averaged measurements from tens of thousands of men and women, aged 25 to 45 , collated by the International Labour Office in Geneva, Rushton (1994) calculated that East Asians, Europeans, and Africans averaged body-size corrected cranial capacities of 1,308 $(S D=37), 1,297(S D=38)$, and $1,241 \mathrm{~cm}^{3}(S D=38)$, respectively.

No exact solution is possible, of course, to the problem of how large the racial differences are in brain size. There is much variability from sample to sample, with a clear overlap of distributions. Nonetheless, the consistency of results found even with the use of different procedures is noteworthy. Rushton (1995) reviewed the world database from (1) autopsies, (2) endocranial volume, (3) cranial capacities estimated from head measurements, and (4) cranial capacities estimated from head measurements and also corrected for body size, and found, respectively, in $\mathrm{cm}^{3}$ or equivalents: East Asians and their descendants $=1,351,1,415,1,335,1,356$ (mean $=$ $1,364)$; Europeans and their descendants $=1,356,1,362$,
$1,341,1,329$ (mean $=1,347)$; and Africans and their descendants $=1,223,1,268,1,284,1,294$ (mean $=1,267)$. The overall mean Asian/European difference favoring Asians was $17 \mathrm{~cm}^{3}$, and the overall mean European/ African difference favoring Europeans was $80 \mathrm{~cm}^{3}$. Within-race differences, due to method of estimation, averaged $31 \mathrm{~cm}^{3}$.

Racial differences in head size appear early in life. As shown in Table 1, head circumference of White children (uncorrected for body size) is greater than that of Black children in each age category by a mean of $0.36 \mathrm{~cm}$ or approximately $0.2 S D$. The greater head size of White children, however, is not a function of greater body size because Black children are taller than White children at both 4 and 7 years (Broman et al., 1987, Tables 7-8, 819). From 7 to 17 years, the White advantage in cranial capacity is $16 \mathrm{~cm}^{3}$ (Lynn, 1993a; Rushton \& Osborne, 1995 ). With these adolescent data, however, there is a striking race $X$ sex interaction, with the White/Black difference present only for males. On the basis of the age $\times$ sex $\times$ race data, Rushton and Osborne (1995) suggested this was due to maturational differences, with girls maturing earlier than boys and Blacks maturing earlier than Whites, resulting in young Black girls being especially larger in body size relative to their counterparts.

Because this section may be contentious for some readers, it is worth detailing the concerns of one reviewer who found it "very misleading." He separated and reexamined published data and concluded that race differences in brain size were very small. For example, he noted that cranial capacities of Blacks in the U.S. Army sampled by Rushton (1992a) fell within the range of Europeans from the International Labour Office sampled by Rushton (1994), and he noted that the U.S. Asian/ White difference showed a race $\times$ sex interaction such that a larger difference existed for Asian women relative to European women than for Asian men relative to $\mathrm{Eu}-$ ropean men. (In Figure 4, for example, Asian men average smaller brains than White men until body size corrections are made.) The reviewer also re-examined the International Labour Office data presented by Rushton (1994). He/she added to the analyses samples from North and South India that had been explicitly excluded by Rushton (1994, pp. 288-289, along with Latin American, North African, and Southeast Asian samples, so as to produce the "clearest" test of the racial gradient) and thereby reduced the White/Black difference to nonsignificance.

We do not doubt that sampling problems occur due to differences in locating populations, measuring heads, calculating cranial capacities, and controlling for body size. Mean differences within races and overlap among races are to be expected. For example, Rushton (1992a) showed that, in the U.S. Army data, Black officers averaged significantly larger crania than Black enlisted personnel $\left(1,369\right.$ vs. $\left.1,355 \mathrm{~cm}^{3}\right)$ and (nonsignificantly) larger crania than White enlisted personnel (1,369 vs. $\left.1,366 \mathrm{~cm}^{3}\right)$. Almost any confirmed hypothesis can be made null if one selects subsets of data. We do not believe such an ap- 
proach is useful for making progress in science. Identifying potential problems in particular studies should lead to calls for additional research, not trenchant acceptance of the null hypothesis. As we have reviewed, deconstructing data has led to the erroneous dismissal of fascinating brain-behavior relationships for six decades. We think that the onus is on critics to gather new data, using modern techniques, if they wish to support their null hypothesis that Asians $=$ Whites $=$ Blacks.

\section{Cognitive Ability}

Overall, racial differences in measured intelligence parallel those found in brain size. Although not shown in Table 1, the three tests of mental ability in the Collaborative Perinatal Project (Bayley at 8 months, StanfordBinet at 4 years, and Wechsler at 7 years) all favored White children. The global literature on cognitive ability was reviewed by Lynn (1991) and Rushton (1995). East Asians, measured in North America and in Pacific Rim countries, typically average IQs in the range of 101 to 111. Caucasoid populations in North America, Europe, and Australasia typically average IQs of from 85 to 115 with an overall mean of 100 . African populations living south of the Sahara, in North America, in the Caribbean, and in Britain typically have mean IQs of from 70 to 90.

Questions remain about the validity of using tests for racial comparisons. Because the tests show similar patterns of internal item consistency and predictive validity for all groups, and because the same differences are found on relatively culture-free tests, many psychometricians think the tests are valid measures of racial differences, at least among people sharing the culture of the authors of the test (Herrnstein \& Murray, 1994; Jensen, 1980; Snyderman \& Rothman, 1987, 1988; Wigdor \& Garner, 1982). Speed of decision making (especially the more complex "odd-man-out" test; Jensen, 1993b) typically shows the same three-way racial pattern as do test scores. Investigations have been done on 9- to 12-yearolds from six countries. Children were asked to decide which of several lights stands out from others and move a hand to press a button. All children can perform the task in less than $1 \mathrm{sec}$, but children with higher IQ scores performed faster (after controlling for movement time) than did those with lower scores. Lynn (1991) found that Asian children from Hong Kong and Japan were faster than were European children from Britain and Ireland, who in turn were faster than African children from South Africa (see also Lynn \& Shigehisa, 1991). With similar tasks, as well as those involving retrieval of well-learned facts from long-term memory, this pattern of racial differences was also found in California (Jensen, 1993b; Jensen \& Whang, 1993, 1994).

Additional analyses have shown that differences in African and European brain size are correlated with differences in mental ability. In a sample of 286 White and Black adolescents, Jensen (1994) found that the greater the difference between White and Black children on 17 cognitive tests, the higher was that tests' correlation with head size $(r=.533, p<.05$; with unreliability of mea- surement controlled, $r=.715, p<.01)$. In a study of 4 . and 7-year-olds, the White and Black samples differed by about 1 standard deviation in IQ and significantly $(p<.001)$ also in head size (White $>$ Black), even with age, height, and weight statistically controlled (Jensen \& Johnson, 1994). It is noteworthy that there was no difference in average head size between White and Black children who were matched on IQ scores (and on age, height, and weight).

\section{EVOLUTION AND BEHAVIORAL GENETICS}

Because of a three-fold increase in relative size of the hominid brain over the last 3 million years in which australopithecenes averaged $500 \mathrm{~cm}^{3}$ (the size of a chimpanzee brain), Homo erectus about $1,000 \mathrm{~cm}^{3}$, and $H o m o$ sapiens about $1,300 \mathrm{~cm}^{3}$, it is reasonable to hypothesize that bigger brains evolved via natural selection for increased intelligence (Jerison, 1973). Metabolically, the human brain is an expensive organ. Representing only $2 \%$ of body mass, the brain uses about $5 \%$ of basal metabolic rate in rats, cats, and dogs, about $10 \%$ in rhesus monkeys and other primates, and about $20 \%$ in humans (Armstrong, 1990). Across species, large brains are related to other life history traits, such as a longer gestation, a slower rate of maturation, a higher rate of offspring survival, a lower reproductive output, and a longer life (Hofman, 1993; Pagel \& Harvey, 1988). From an adaptationist perspective, unless large brains had contributed substantially to evolutionary fitness (defined as increased survival of genes through successive generations), they would not have evolved.

The sexual dimorphism in cranial size and cognitive ability likely originated partly through evolutionary selection of men's hunting ability (Ankney, 1992; Kolakowski \& Malina, 1974) and partly through the reproductive success socially dominant men have traditionally enjoyed (Lynn, 1994). Race differences in cranial capacity may have originated from evolutionary pressures in colder climates for greater intelligence (Rushton, 1995). The brain size of individuals, of course, is also affected by nutrition and experience, most obviously through illness and trauma.

Despite such selection, cranial size, and by inference brain size, retains moderate heritability in modern humans. Rushton and Osborne (1995) studied genetic and environmental contributions to cranial size among 236 pairs of adolescent twins (472 individuals) aged 13 to 17 years. Cranial sizes were calculated for 187 boys and 285 girls, 222 Whites and 250 Blacks; age, sex, and race differences have been reported in relevant sections above. The genetic contribution to cranial size for the total sample ranged from $38 \%$ to $51 \%$, depending on particular adjustments made for body size. Environmental effects common to both twins, such as parental socioeconomic status, ranged from $6 \%$ to $20 \%$ and environmental effects unique to each twin, such as illness and trauma, ranged from $42 \%$ to $52 \%$. Heritability estimates did not 
vary significantly by sex or race, although there was a trend for heritabilities to be lower in Blacks than in Whites. Eysenck (1991a) and Lynn (1993b) have applied a nutrient deficiency hypothesis to explain some of the race differences.

The heritability of cognitive ability is now well established from numerous adoption, twin, and family studies (Bouchard \& McGue, 1981). Particularly noteworthy are the heritabilities of around $80 \%$ found in adult twins reared apart (Bouchard, Lykken, McGue, Segal, \& Tellegen, 1990; Pedersen, Plomin, Nesselroade, \& McClearn, 1992). Moderate to substantial genetic influence on IQ has also been found in studies of non-Whites, including African Americans (Osborne, 1980; Scarr, Weinberg, \& Waldman, 1993) and Japanese (Lynn \& Hattori, 1990).

Transracial adoption studies suggest a genetic contribution to the between-group differences. Studies of Korean and Vietnamese children adopted into White American and White Belgian homes have shown that, although as babies many had been hospitalized for malnutrition, they grew to excel in academic ability with IQs 10 points or more higher than their adoptive national norms (Clark \& Hanisee, 1982; Frydman \& Lynn, 1989; Winick, Meyer, \& Harris, 1975). By contrast, Weinberg, Scarr, and Waldman (1992) found that at age 17, Black and mixed-race children adopted into White middleclass families performed at a lower level than the White siblings with whom they had been raised. Regardless, the importance of genetics for explaining among-group differences in intelligence remains much more controversial than for explaining within-group differences (Brody, 1992; Rushton, 1995; Waldman, Weinberg, \& Scarr, 1994).

\section{CONCLUSION}

Differences in cognitive abilities are correlated with differences in brain size, and both brain size and cognitive ability are correlated with age, sex, social class, and race. As noted earlier, correlation does not prove cause and effect, but, just as zero correlations provide no support for a hypothesis of cause and effect, non-zero correlations do provide support. We are convinced that the brain-size/cognitive-ability correlations that we have reported are, in fact, due to cause and effect. This is because we are unaware of any variable, other than the brain, that can directly mediate cognitive ability.

Some have suggested that perhaps increased intellectual activity and/or improved nutrition cause higher cognitive ability. But, just as physical activity and/or better nutrition can only increase physical strength via their effects on muscles, increased cognitive "strength" can occur only via increased brain function. Of course, brain size is not the only mediator of brain function; Miller's (1994) review suggests that amount of brain myelination is related to IQ (as in work by Schultz, 1991; Willerman, Schultz, Rutledge, \& Bigler, 1994). Nonetheless, we believe that the important research questions are as follows: (1) What is responsible for these group differences in brain size; that is, are they genetically and/or environ- mentally caused? and (2) Why does variation in brain size correlate with differences in cognitive ability?

Numerous problem areas remain to be researched. For example, it is not known whether women have fewer neurons than do men; there may be greater cortical packing density in women, and thus, it is myelin thickness or some other variable that is responsible for the sex differences in brain size (Haug, 1987). In a postmortem study of brain tissue from the temporal lobes of 5 women and 4 men, Witelson, Glezer, and Kigar (1995) supported the hypothesis that women's neurons are packed more tightly. It is unknown, however, whether tightly packed neurons are more or less efficient than are those that are more widely spaced; the latter may allow a greater number of synaptic connections. Serious paradoxes also require resolution. For example, White women have brain sizes equal to or smaller than those of Black men, but nonetheless score higher than do Black men in general cognitive ability. Additional research with magnetic resonance imaging or behavior genetic techniques is certain to enrich knowledge of these important relationships. MRI may identify features of the brain that correlate even more highly with IQ than does volume (some possibilities are neuronal density, white/gray contrast, ventricle/brain ratio, and various specific brain regions). More generally, as Broca and other nineteenth-century scientists conjectured so long ago, it may be the complexities of the convolutions of the brain, and the varieties and efficiencies of its commissures, rather than its actual size, that is related to intellectual ability and that differentiates populations.

\section{REFERENCES}

ANDREASEN, N. C. (1993, November). Sex differences in the brain: Perspectives from neuroimaging. Paper presented at a meeting of the Society for Neuroscience, Washington, DC.

Andreasen, N. C., Ehrhardt, J. C., Swayze, V. W., Alliger, R. J., Yuh, W. T. C., Cohen, G., \& Ziebell, S. (1990). Magnetic resonance imaging of the brain in schizophrenia. Archives of General Psychiatry, 47, 35-44.

Andreasen, N. C., Flaum, M., Swayze, V., O’Leary, D. S., AlliGer, R., Cohen, G., Ehrhardt, J., \& Yuh, W. T. C. (1993). Intelligence and brain structure in normal individuals. American Journal of Psychiatry, 150, 130-134.

ANKNEY, C. D. (1992). Sex differences in relative brain size: The mismeasure of woman, too? Intelligence, 16, 329-336.

ANKNEY, C. D. (1995). Sex differences in brain size and mental abilities: Comments on R. Lynn and D. Kimura. Personality \& Individual Differences, 18, 423-424.

ARMSTRONG, E. (1990). Brains, bodies and metabolism. Brain, Behavior \& Evolution, 36, 166-176.

BAKER, J. R. (1974). Race. Oxford: Oxford University Press.

Beals, K. L., SMith, C. L., \& DoDD, S. M. (1984). Brain size, cranial morphology, climate, and time machines. Current Anthropology, 25, 301-330.

BogaerT, A. F., \& Rushton, J. P. (1989). Sexuality, delinquency and $r / K$ reproductive strategies: Data from a Canadian university sample. Personality \& Individual Differences, 10, 1071-1077.

Bouchard, T. J., JR., Lykken, D. T., MCGue, M., Segal, N. L., \& TelleGEN, A. (1990). Sources of human psychological differences: The Minnesota study of twins reared apart. Science, 250, 223-228.

Bouchard, T. J., JR., \& MCGUE, M. (1981). Familial studies of intelligence: A review. Science, 212, 1055-1059.

BRANDT, I. (1978). Growth dynamics of low-birth weight infants with 
emphasis on the perinatal period. In F. Falkner \& J. M. Tanner (Eds.), Human growth (Vol. 2, pp. 557-617). New York: Plenum

Bray, P. F., Shields, W. D., Wolcott, G. J., \& Madsen, J. A. (1969). Occipitofrontal head circumference-An accurate measure of intracranial volume. Journal of Pediatrics, 75, 303-305.

Broca, P. (1861). Sur le volume et la forme du cerveau suivant les individus et suivant les races. Bulletins et mémoires de la Société d'Anthropologie de Paris, 2, 139-207, 301-321, 441-446.

Brody, N. (1992). Intelligence. New York: Academic Press.

Broman, S. H., Nichols, P. L. \& KenNedy, W. A. (1975). Preschool IQ Prenatal and early development correlates. Hillsdale, NJ: Erlbaum.

Broman, S. H., Nichols, P. L., Shaughnessy, P., \& Kennedy, W. (1987). Retardation in young children. Hillsdale, NJ: Erlbaum.

CATTELL, R. B. (1982). The inheritance of personality and ability. New York: Academic Press.

Clark, E. A., \& HaniseE, J. (1982). Intellectual and adaptive performance of Asian children in adoptive American settings. Developmental Psychology, 18, 595-599.

CoOKe, R. W. I., Lucas, A., Yudkin, P. L. N., \& Pryse-Davies, J. (1977). Head circumference as an index of brain weight in the fetus and new born. Early Human Development, 112, 145-149.

DaRwin, C. (1871). The descent of man. London: Murray.

Dekaban, A. S., \& Sadowsky, D. (1978). Changes in brain weights during the span of human life: Relation of brain weights to body heights and body weights. Annals of Neurology, 4, 345-356.

DeMyer, M. K., Gilmor, R. L., Hendrie, H. C., DeMyer, W. E., AuGUSTYN, G. T., \& JACKSON, R. K. (1988). Magnetic resonance brain images in schizophrenic and normal subjects: Influence of diagnosis and education. Schizophrenia Bulletin, 14, 2]-32.

Egan, V., Chiswick, A., Santosh, C., Naidu, K., Rimmington, J. E. \& BEST, J. J. K. (1994). Size isn't everything: A study of brain volume, intelligence and auditory evoked potentials. Personality \& Individual Differences, 17, 357-367.

Egan, V., Wickett, J. C., \& Vernon, P. A. (1995). Brain size and intelligence: Erratum, addendum, and correction. Personality \& Individual Differences, 19, 113-115.

ESTABROOKS, G. H. (1928). The relation between cranial capacity, relative cranial capacity and intelligence in school children. Journal of Applied Psychology, 12, 524-529.

EYSENCK, H. J. (1991a). Race and intelligence: An alternative hypothesis. Mankind Quarterly, 32, 133-136.

EYSENCK, H. J. (1991b). Raising IQ through vitamin and mineral supplementation: An introduction. Personality \& Individual Differences, 12, 329-333.

Fisch, R. O., Bilek, M. K., Horrobin, J. M., \& Chang, P. N. (1976) Children with superior intelligence at 7 years of age. American Journal of Diseases in Children, 130, 481-487.

FisHer, R. A. (1970). Statistical methods for research workers (14th ed.). New York: Hafner Press.

Flaum, M., Andreasen, N. C., Swayze, V. W., II, O'Leary, D. S., \& ALLIGER, R. J. (1994). IQ and brain size in schizophrenia. Psychiatry Research, 53, 243-257.

FRYDMAN, M., \& LYNN, R. (1989). The intelligence of Korean children adopted in Belgium. Personality \& Individual Differences, 10, 1323 1326.

GalTON, F. (1888). Head growth in students at the University of Cambridge. Nature, 38, 14-15.

GOTTFREDSON, L. S. (1986). (Ed.) The $g$ factor in employment. Journal of Vocational Behavior, 29, 293-450.

GouLd, S. J. (1978). Morton's ranking of races by cranial capacity. Science, 200, 503-509.

Gould, S. J. (1981). The mismeasure of man. New York: Norton.

Gur, R. C., Mozley, P. D., Resnick, S. M., Gottlieb, G. L., Kohn, M., Zimmerman, R., Herman, G., Atlas, S., Grossman, R., Berretta, D., ERwin, R., \& Gur, R. E. (1991). Gender differences in age effect on brain atrophy measured by magnetic resonance imaging. Proceedings of the National Academy of Sciences, 88, 2845-2849.

Hack, M., Breslau, N., Weissman, B., Aram, D., Klein, N., \& BoRAWSKI, E. (1991). Effect of very low birth weight and subnormal head size on cognitive abilities at school age. New England Journal of Medicine, 325, 231-237.

Haier, R. J., Chueh, D., Touchette, P., Lott, I., Buchsbaum, M. S.,
Macmillan, D., Sandman, C., LaCasse, L., \& Sosa, E. (1995) Brain size and cerebral glucose metabolic rate and nonspecific mental retardation and Down syndrome. Intelligence, 20, 191-210.

Harvey, I., Persaud, R., Ron, M. A., Baker, G., \& Murray, R. M. (1994) Volumetric MRI measurements in bipolars compared with schizophrenics and healthy controls. Psychological Medicine, 24, 689-699.

HaUG, H. (1987). Brain sizes, surfaces, and neuronal sizes of the cor tex cerebri: A stereological investigation of man and his variability and a comparison with some species of mammals (primates, whales, marsupials, insectivores, and one elephant). American Journal of Anatomy, 180, 126-142.

Henneberg, M., Budnik, A., Pezacka, M., \& Puch, A. E. (1985). Head size, body size and intelligence: Intraspecific correlations in Homo sapiens sapiens. Homo, 36, 207-218.

Herrnstein, R. J., \& Murray, C. (1994). The bell curve. New York: Free Press.

Ho, K. C., Roessmann, U., Straumfjord, J. V., \& Monroe, G. (1980a). Analysis of brain weight: I. Adult brain weight in relation to sex, race, and age. Archives of Pathology \& Laboratory Medicine, 104, 635-639.

Ho, K. C., Roessmann, U., Straumfjord, J. V., \& Monroe, G. (1980b). Analysis of brain weight: II. Adult brain weight in relation to body height, weight, and surface area. Archives of Pathology \& Laboratory Medicine, 104, 640-645.

HoFman, M. A. (1991). The fractal geometry of convoluted brains. Journal für Hirnforschung, 32, 103-111.

Hofman, M. A. (1993). Encephalization and the evolution of longevity in mammals. Journal of Evolutionary Biology, 6, 209-227.

Hofman, M. A., \& SwaAB, D. F. (1991). Sexual dimorphism of the human brain: Myth and reality. Experimental Clinical Endocrinol ogy, 98, 161-170.

Holloway, R. L. (1980). Within-species brain-body weight variability: A reexamination of the Danish data and other primate species American Journal of Physical Anthropology, 53, 109-121.

Hooton, E. A. (1939). The American criminal (Vol. 1). Cambridge, MA: Harvard University Press.

HUNTER, J. E., \& SCHMIDT, F. L. (1990). Methods of meta-analysis. Correcting error and bias in research findings. Newbury, CA: Sage.

JACKSON, D. N. (1993, July 17-21). Sex differences in intellectual ability. Paper presented at a meeting of the International Society for the Study of Individual Differences, Baltimore.

JACKSON, D. N. (1995, May). Sex differences in general cognitive ability. Paper presented at a meeting of the International Behavioral Development Symposium: Biological Basis of Sexual Orientation and Sex-Typical Behavior, Minot State University, Minot, ND.

Jensen, A. R. (1980). Bias in mental testing. New York: Free Press. Jensen, A. R. (1993a). Psychometric G and achievement. In B. R. Gifford (Ed.), Policy perspectives on educational testing ( $\mathrm{pp}$. 117-227). Boston: Kluwer.

JENSEN, A. R. (1993b). Spearman's hypothesis tested with chronometric information processing tasks. Intelligence, 17, 47-77.

Jensen, A. R. (1994). Psychometric $g$ related to differences in head size. Personality \& Individual Differences, 17, 597-606.

Jensen, A. R., \& Johnson, F. W. (1994). Race and sex differences in head size and IQ. Intelligence, 18, 309-333.

JENSEN, A. R., \& SinHA, S. N. (1993). Physical correlates of human intelligence. In P. A. Vernon (Ed.), Biological approaches to the study of human intelligence (pp. 139-242). Norwood, NJ: Ablex

JENSEN, A. R., \& Whang, P. A. (1993). Reaction times and intelligence: A comparison of Chinese-American and Anglo-American children. Journal of Biosocial Science, 25, 397-410.

JENSEN, A. R., \& WhaNG, P. A. (1994). Speed of accessing arithmetic facts in long-term memory: A comparison of Chinese-American and AngloAmerican children. Contemporary Educational Psychology, 19, 1-12.

JERISON, H. J. (1963). Interpreting the evolution of the brain. Human Biology, 35, 263-291.

JERISON, H. J. (1973). Evolution of the brain and intelligence. New York: Academic Press.

Jernigan, T. L., ArChibald, S. L., Berhow, M. T., Sowell, E. R., FosTER, D. S., \& HesSELINK, J. R. (1991). Cerebral structure on MRI, part 1: Localization of age-related changes. Biological Psychiatry, 29, 55-67. 
Johnson, R. C., McClearn, G. E., Yuen, S., Nagoshi, C. T., Ahern, F. M., \& COLE, R. E. (1985). Galton's data a century later. American Psychologist, 40, 875-892.

KAMIN, L. J. (1974). The science and politics of IQ. Hillsdale, NJ Erlbaum.

KANDEL, E. R. (1991). Nerve cells and behavior. In E. R. Kandel, J. H Schwartz, \& T. M. Jessell (Eds.), Principles of neural science (3rd ed., pp. 18-32). New York: Elsevier.

Kimura, D. (1992). Sex differences in the brain. Scientific American, 267, 119-125.

Klein, R. E., Freeman, H. E., Kagan, J., Yarborough, C., \& HABICHT, J. P. (1972). Is big smart? The relation of growth to cognition. Journal of Health \& Social Behavior, 13, 219-250.

Kolakowski, D., \& Malina, R. M. (1974). Spatial ability, throwing accuracy, and man's hunting heritage. Nature, 251, 410-412.

Kretschmer, E. (1936). Physique and character (2nd ed.). London Routledge.

Krogman, W. M. (1970). Growth of head, face, trunk and limbs in Philadelphia White and Negro children of elementary and high school age. Monographs of the Society for Research in Child Development, 35 (No. 136).

Lewontin, R. C., Rose, S., \& Kamin, L. J. (1984). Not in our genes. New York: Pantheon.

LyNN, R. (1990). New evidence on brain size and intelligence: A comment on Rushton and Cain and Vanderwolf. Personality \& Individual Differences, 11, 795-797.

LYNN, R. (1991). Race differences in intelligence: A global perspective. Mankind Quarterly, 31, 255-296.

LYNN, R. (1993a). Further evidence for the existence of race and sex differences in cranial capacity. Social Behavior \& Personality, 21, 89-92.

LYNN, R. (1993b). Nutrition and intelligence. In P. A. Vernon (Ed.), Biological approaches to the study of human intelligence (pp. 243 258). Norwood, NJ: Ablex.

LyNN, R. (1994). Sex differences in intelligence and brain size: A paradox resolved. Personality \& Individual Differences, 17, 257-271

LYNN, R., \& HaTtORI, K. (1990). The heritability of intelligence in Japan. Behavior Genetics, 20, 545-546.

LYNN, R., \& JindaL, S. (1993). Positive correlations between brain size and intelligence: Further evidence from India. Mankind Quarterly, 34, 109-123.

LyNN, R., \& SHIGEHISA, T. (1991). Reaction times and intelligence: A comparison of Japanese and British children. Journal of Biosocial Science, 23, 409-416.

Mascie-Taylor, C. G. N., \& Gibson, J. B. (1978). Social mobility and IQ components. Journal of Biosocial Science, 10, 263-276.

Michael, J. A. (1988). A new look at Morton's craniological research. Current Anthropology, 29, 349-354.

MiLleR, E. M. (1926). Brain capacity and intelligence (Monograph Series No. 4). Sydney: Australian Association for Psychology and Philosophy.

MiLLER, E. M. (1994). Intelligence and brain myelination: A hypothesis. Personality \& Individual Differences, 17, 803-832.

MorTon, S. G. (1849). Observations on the size of the brain in various races and families of man. Proceedings of the Academy of Natural Sciences Philadelphia, 4, 221-224.

Murdock, J., \& Sullivan, L. R. (1923). A contribution to the study of mental and physical measurements in normal school children. American Physical Education Review, 28, 209-330.

OsBorne, R. T. (1980). Twins: Black and white. Athens, GA: Foundation for Human Understanding.

OsboRne, R. T. (1992). Cranial capacity and IQ. Mankind Quarterly, 32, 275-280

Packard, G. C., \& Boardman, T. J. (1988). The misuse of ratios, indices, and percentages in ecophysiological research. Physiological Zoology, 61, 1-9.

Pagel, M. D., \& HaRvey, P. H. (1988). How mammals produce largebrained offspring. Evolution, 42, 948-957.

Pakkenberg, H., \& Volgt, J. (1964). Brain weight of the Danes. Acta Anatomica, 56, 297-307.

Passingham, R. E. (1979). Brain size and intelligence in man. Brain. Behavior \& Evolution, 16, 253-270.

PEARL, R. (1906). On the correlation between intelligence and the size of the head. Journal of Comparative Neurology \& Psychology, 16 , 189-199.

Pearlson, G. D., Kim, W. S., Kubos, K. L., Moberg, P. J., Jayaram, G. Bascom, M. J., Chase, G. A., Goldfinger, A. D., \& Tune, L. E. (1989) Ventricle-brain ratio, computed tomographic density, and brain area in 50 schizophrenics. Archives of General Psychiatry, 46, 690-697.

Pearson, K. (1906). On the relationship of intelligence to size and shape of head, and to other physical and mental characters. Biometrika, 5, 105-146.

Pedersen, N. L., Plomin, R., Nesselroade, J. R., \& McClearn, G. D. (1992). A quantitative genetic analysis of cognitive abilities during the second half of the life span. Psychological Science, 3, 346-353.

Pfefferbaum, A., Mathalon, D. H., Sullivan, E. V., Rawles, J. M., ZIPURSKY, R. B., \& LIM, K. O. (1994). A quantitative magnetic resonance imaging study of changes in brain morphology from infancy to late adulthood. Archives of Neurology, 51, 874-887.

Pool, R. (1994). Eve's rib: Searching for the biological roots of sex differences. New York: Crown.

PORTEUS, S. D. (1937). Primitive intelligence and environment. New York: Macmillan.

Raz, N., Torres, I. J., SPencer, W. D., Millman, D., BaerTsChi, J. C., \& SARPEL, G. (1993). Neuroanatomical correlates of age-sensitive and age-invariant cognitive abilities: An in vivo $\mathrm{MRI}$ investigation. Intelligence, 17, 407-422.

ReEd, T. E., \& JENSEN, A. R. (1993). Cranial capacity: New Caucasian data and comments on Rushton's claimed Mongoloid-Caucasoid brain size differences. Intelligence, 17, 423-431.

REID, R. W., \& Mulligan, J. H. (1923). Relation of cranial capacity to intelligence. Journal of the Royal Anthropological Institute, 53, 322-331.

RESNICK, S. M. (1995, May). Gender differences in brain structure and function in the elderly. Paper presented at a meeting of the International Behavioral Development Symposium: Biological Basis of Sexual Orientation and Sex-Typical Behavior, Minot State University, Minot, ND.

RosentHAL, R. (1984). Meta-analytic procedures for social research. Newbury Park, CA: Sage.

Rushton, J. P. (1988a). Race differences in behaviour: A review and evolutionary analysis. Personality \& Individual Differences, 9, 1009-1024.

RushToN, J. P. (1988b). The reality of racial differences: A rejoinder with new evidence. Personality \& Individual Differences, 9, 1035-1040

Rushton, J. P. (1992a). Cranial capacity related to sex, rank, and race in a stratified random sample of 6,325 U.S. military personnel. Intelligence, 16, 401-413.

Rushton, J. P. (1992b). Life history comparisons between Orientals and Whites at a Canadian university. Personality \& Individual Differences, 13, 439-442.

Rushton, J. P. (1994). Sex and race differences in cranial capacity from International Labour Office data. Intelligence, 19, 281-294.

Rushton, J. P. (1995). Race, evolution and behavior: A life-history perspective. New Brunswick, NJ: Transaction Publishers.

RUSHTON, J. P., \& ANKNEY, C. D. (1995). Brain size matters: A reply to Peters. Canadian Journal of Experimental Psychology, 49, 562-569.

Rushton, J. P., \& Osborne, R. T. (1995). Genetic and environmental contributions to cranial capacity estimated in Black and White adolescents. Intelligence, 20, 1-13.

SCarr, S., Weinberg, R. A., \& Waldman, I. D. (1993). IQ correlations in transracial adoptive families. Intelligence, 17, 541-555.

SCHAie, K. W., \& STROTHER, C. R. (1968). A cross-sequential study of age changes in cognitive behavior. Psychological Bulletin, 70, 671-680.

SCHREIDER, E. ( 1966). Brain weight correlations calculated from original results of Paul Broca. American Journal of Physical Anthropology, 25, 153-158.

SCHreIder, E. (1968). Quelques corrélations somatiques des tests mentaux. Homo, 19, 38-43.

ScHUlTz, R. T. (1991). The relationship between intelligence and gray-white matter image contrast: A MRI study of healthy college students. Unpublished doctoral dissertation, University of Texas, Austin.

SNyderman, M., \& Rothman, S. (1987). Survey of expert opinion on intelligence and aptitude testing. American Psychologist, 42, 137-144.

SNyderman, M., \& Rothman, S. (1988). The I $Q$ controversy, the media, and public policy. New Brunswick, $\mathrm{NJ}$ : Transaction.

Sommerville, R. C. (1924). Physical, motor and sensory traits. Archives of Psychology, 12, 1-108. 
SoRoKIN, P. (1927). Social mobility. New York: Harper.

STERNBERG, R. J. (1988). The triarchic mind: A new theory of human intelligence. New York: Penguin.

Stort, D. H. (1983). Brain size and "intelligence." British Journal of Developmental Psychology, 1, 279-287.

Stringer, C. B., \& ANDREws, P. (1988). Genetic and fossil evidence for the origin of modern humans. Science, 239, 1263-1268.

STUMPF, H., \& JACKSON, D. N. (1994). Gender-related differences in cognitive abilities: Evidence from a medical school admissions testing program. Personality \& Individual Differences, 17, 335-344.

SusANNE, C. (1979). On the relationship between psychometric and anthropometric traits. American Journal of Physical Anthropology, $51,421-423$.

SwaAB, D. F., \& Hofman, M. A. (1984). Sexual differentiation of the human brain: A historical perspective. In G. J. De Vries, J. P. C. De Bruin, H. B. M. Uylings, \& M. A. Corner (Eds.), Progress in brain research (Vol. 61, pp. 361-374). Amsterdam: Elsevier.

Teasdale, T. W., \& Pakkenberg, B. (1988). The association between intelligence level and brain volume measures: A negative finding. Scandinavian Journal of Psychology, 29, 123-125.

Terman, L. M. (1926/1959). Genetic studies of genius: Vol. 1. Mental and physical traits of a thousand gifted children (2nd ed.). Stanford, CA: Stanford University Press.

ToBiAs, P. V. (1970). Brain-size, grey matter and race-Fact or fiction? American Journal of Physical Anthropology, 32, 3-26.

TOPINARD, P. (1878). Anthropology. London: Chapman \& Hall.

VAN VALEN, L. (1974). Brain size and intelligence in man. American Journal of Physical Anthropology, 40, 417-424.

VoIGT, J., \& PAKKENBERG, H. (1983). Brain weight of Danish children. Acta Anatomica, 116, 290-301.

VOYER, D., Voyer, S., \& Bryden, M. P. (1995). Magnitude of sex differences in spatial abilities: A meta-analysis and consideration of critical variables. Psychological Bulletin, 117, 250-270.
Waldman, I. D., Weinberg, R. A., \& Scarr, S. (1994). Racial group differences in IQ in the Minnesota Transracial Adoption Study: A reply to Levin and Lynn. Intelligence, 19, 29-44.

WALLER, J. H. (1971). Achievement and social mobility: Relationships among IQ score, education, and occupation in two generations. Social Biology, 18, 252-259.

Weinberg, R. A., SCARR, S., \& Waldman, I. D. (1992). The Minnesota Transracial Adoption Study: A follow-up of IQ test performance at adolescence. Intelligence, 16, 117-135.

Weinberg, W. A., Dietz, S. G., Penick, E. C., \& McAlister, W. H (1974). Intelligence, reading achievement, physical size and social class. Journal of Pediatrics, 85, 482-489.

WicketT, J. C., Vernon, P. A., \& LeE, D. H. (1994). In vivo brain size head perimeter, and intelligence in a sample of healthy adult females. Personality \& Individual Differences, 16, 831-838.

WigDOR, A. K., \& GARNER, W. R. (1982). (Eds.) Ability testing: Uses, consequences, and controversies. Washington, DC: National Academy Press.

Willerman, L., Schultz, R., Rutledge, J. N., \& Bigler, E. D (1991). In vivo brain size and intelligence. Intelligence, 15, 223-228

Willerman, L., Schultz, R., Rutledge, J. N., \& Bigler, E. D. (1994). Brain structure and cognitive function. In C. R. Reynolds (Ed.), Cognitive assessment: A multi-disciplinary assessment (pp. 35-55). New York: Plenum.

WinICK, M., MEYER, K. K., \& HarRIS, R. C. (1975). Malnutrition and environmental enrichment by early adoption. Science, 190, 1173 1175 .

Witelson, S. F., Glezer, I. I., \& Kigar, D. L. (1995). Women have greater density of neurons in posterior temporal cortex. Journal of Neuroscience, 15, 3418-3428.

Yeo, R. A., Turkheimer, E., Raz, N., \& Bigler, E. D. (1987). Volumetric asymmetries of the human brain: Intellectual correlates. Brain \& Cognition, 6, 15-23.

APPENDIX

Intelligence and Head/Brain Size

\begin{tabular}{|c|c|c|c|c|}
\hline \multirow[b]{2}{*}{ Source } & \multirow[b]{2}{*}{ Sample } & \multicolumn{2}{|c|}{ Measurement } & \multirow[b]{2}{*}{ Correlatio } \\
\hline & & Head/Brain & Test & \\
\hline \multicolumn{5}{|c|}{ A. Children and Adolescents by External Head Measurements } \\
\hline Pearson (1906) & $\begin{array}{l}\text { 4,386 British children } \\
\text { ( } 2,198 \text { boys, } 2,188 \text { girls) aged } 3 \\
\text { to } 20 ; \text { standardized to age } 12\end{array}$ & length & teachers' estimate & .11 \\
\hline Murdock \& Sullivan (1923) & $\begin{array}{l}595 \text { American children aged } 6 \text { to } 17 \\
\text { standardized by age and sex }\end{array}$ & perimeter & IQ tests & .22 \\
\hline Estabrooks (1928) & $\begin{array}{l}251 \text { European American children } \\
\text { ( } 102 \text { boys, } 149 \text { girls) aged } 6 \text { years }\end{array}$ & capacity & Binet & .19 \\
\hline Porteus (1937) & 200 White Australian children & perimeter & Porteus maze & .20 \\
\hline $\begin{array}{l}\text { Robinow (1968, cited in } \\
\text { Jensen \& Sinha, 1993) }\end{array}$ & $\begin{array}{l}300 \text { boys and girls aged } 3 \text { to } 13 \\
\text { studied longitudinally, with } \\
\text { age standardized }\end{array}$ & perimeter & IQ tests & .18 \\
\hline $\begin{array}{l}\text { Klein, Freeman, Kagan, } \\
\text { Yarborough, \& Habicht } \\
(1972)\end{array}$ & $\begin{array}{l}170 \text { Guatemalan Amerindian } \\
\text { children aged } 3 \text { to } 6\end{array}$ & perimeter & $\begin{array}{l}\text { knowledge tests } \\
\text { standardized with } \\
\text { age-sex groups. }\end{array}$ & .28 \\
\hline $\begin{array}{l}\text { Weinberg, Dietz, Penick, } \\
\text { \& McAlister (1974) }\end{array}$ & $\begin{array}{l}334 \text { European American boys } \\
\text { aged } 8 \text { to } 9 \text { years }\end{array}$ & perimeter & WISC & .35 \\
\hline $\begin{array}{l}\text { Swan et al. (undated, } \\
\text { cited in Cattell, 1982, \& } \\
\text { Jensen \& Sinha, 1993) }\end{array}$ & 547 children, age controlled & perimeter & IQ tests & .11 \\
\hline \multirow[t]{2}{*}{ Broman et al. (1987) } & $\begin{array}{l}\text { 18,907 African American } \\
\text { boys and girls aged } 7 \text { years }\end{array}$ & perimeter & WISC & .19 \\
\hline & $\begin{array}{l}\text { 17,241 European American } \\
\text { boys and girls aged } 7 \text { years }\end{array}$ & perimeter & WISC & .24 \\
\hline \multirow[t]{3}{*}{ Lynn (1990) } & 310 Irish boys and girls aged 9 to 10 & perimeter & PMAT & .18 \\
\hline & 205 Irish children aged 9 years & perimeter & matrices & .26 \\
\hline & 91 English children aged 9 years & perimeter & matrices & .26 \\
\hline
\end{tabular}







APPENDIX (Continued)

\begin{tabular}{|c|c|c|c|c|}
\hline \multirow[b]{2}{*}{ Source } & \multirow[b]{2}{*}{ Sample } & \multicolumn{2}{|c|}{ Measurement } & \multirow[b]{2}{*}{ Correlation } \\
\hline & & Head/Brain & Test & \\
\hline Andreasen et al. (1990) & $\begin{array}{l}54 \text { mainly ( } 99 \% \text { ) European American } \\
\text { schizophrenics ( } 36 \text { men, } 18 \text { women) } \\
\text { with a mean age of } 34 \text { years }\end{array}$ & MRI frontal lobe & educational level & .31 \\
\hline Flaum et al. (1994) & $\begin{array}{l}72 \text { schizophrenic patients ( } 52 \text { men and } \\
22 \text { women) with height controlled }\end{array}$ & MRI volume & WAIS-R & .11 \\
\hline Harvey et al. (1994) & $\begin{array}{l}26 \text { British bipolar patients ( } 62 \% \text { women, } \\
65 \% \text { Caucasian) aged } 21-49\end{array}$ & MRI volume & NART & .38 \\
\hline Harvey et al. (1994) & $\begin{array}{l}48 \text { British schizophrenic patients } \\
\text { (59\% women, 65\% Caucasian) } \\
\text { aged 19-61 }\end{array}$ & MRI volume & NART & .24 \\
\hline Haier et al. (1995) & $\begin{array}{l}26 \text { mixed mild mental retardation, } \\
\text { Down syndrome, and college student } \\
\text { controls ( } 38 \% \text { controls, } 54 \% \text { males) } \\
\text { with a mean age of } 28 . \text { Corrected for } \\
\text { extended IQ range }\end{array}$ & MRI volume & WAIS-R & .36 \\
\hline Summary of $C$ & $\begin{array}{l}\text { Number of samples: } 7 \\
\text { Total } N: 312 \\
\text { Range of } r: .07-.38 \\
\text { Unweighted mean } r: .24 \\
N \text {-weighted mean } r: .22\end{array}$ & & & \\
\hline \multicolumn{5}{|c|}{ D. Adult Nonclinical Samples by Imaging Techniques } \\
\hline Pearlson et al. (1989) & $\begin{array}{l}84 \text { normal Americans of racially } \\
\text { heterogeneous background } \\
(63 \% \text { White, } 35 \% \text { men, with a } \\
\text { mean age of } 40) \text { used as a control } \\
\text { group for a study of schizophrenics }\end{array}$ & $\begin{array}{l}\text { CAT area of } \\
\text { a single slice }\end{array}$ & occupational status & $.35^{*}$ \\
\hline $\begin{array}{l}\text { Andreasen et al. } \\
\text { (1990) }\end{array}$ & $\begin{array}{l}47 \text { European Americans } \\
\text { ( } 28 \text { men, } 19 \text { women) with } \\
\text { a mean age of } 35 \text { years }\end{array}$ & MRI frontal lobe & educational level & .33 \\
\hline Willerman et al. (1991) & $\begin{array}{l}40 \text { European American university } \\
\text { students ( } 20 \text { men, } 20 \text { women). } \\
\text { Corrected for sex, body size, and } \\
\text { the extended IQ range }\end{array}$ & MRI volume & WAIS & .35 \\
\hline $\begin{array}{l}\text { Andreasen et al. } \\
\text { (1993) }\end{array}$ & $\begin{array}{l}67 \text { European American adults } \\
(37 \text { men, } 30 \text { women) with } \\
\text { a mean age of } 38\end{array}$ & MRI volume & WAIS & .38 \\
\hline Raz et al. (1993) & $\begin{array}{l}29 \text { European American adults } \\
(17 \text { men, } 12 \text { women) aged } 18 \text { to } 78\end{array}$ & MRI volume & CFIT & .43 \\
\hline Harvey et al. (1994) & $\begin{array}{l}34 \text { normal British controls } \\
\text { (45\% women, } 62 \% \text { Caucasian) } \\
\text { aged } 19 \text { to } 49 \text { years }\end{array}$ & MRI volume & NART & .69 \\
\hline Wickett et al. (1994) & $\begin{array}{l}40 \text { White Canadian women aged } \\
20-30 \text { years; height and weight } \\
\text { partialed out and corrected for } \\
\text { restriction of range }\end{array}$ & MRI volume & MAB & $.54 \dagger$ \\
\hline Egan et al. (1994) & $\begin{array}{l}40 \text { British military (unreported } \\
\text { race and sex breakdown) aged } \\
23 \text { years. Corrected for height, } \\
\text { weight, and restricted range }\end{array}$ & MRI volume & WAIS-R & $.48 \dagger$ \\
\hline Summary of $D$ & $\begin{array}{l}\text { Number of samples: } 8 \\
\text { Total } N: 381 \\
\text { Range of } r: .33-.69 \\
\text { Unweighted mean } r: .44 \\
N \text {-weighted mean } r: .42\end{array}$ & & & \\
\hline
\end{tabular}

(Manuscript received April 24, 1994; revision accepted for publication May 17, 1995.) 